TEME, г. XLIV, бр. 3, јул - септембар 2020, стр. 1119-1121

\author{
Приказ дела https://doi.org/10.22190/TEME190521057M \\ Примљено: 21. 5. 2019. \\ Одобрено за штампу: 1. 10. 2020.
}

\title{
КОЖА У ИГРИ: ЕТИКА НА ДЕЛУ ${ }^{a}$
}

Александар С. Мојашевић

Универзитет у Нишу, Правни факултет, Ниш, Србија

mojasevic@prafak.ni.ac.rs

Најновија књига Кожа у игри - асиметрије скривене у свакодневници, чији је аутор један од водећих интелектуалаца данашњице (можда би се аутор увредио овим изразом, те, ипак, користимо лексему мислилаи) Насим Николас Талеб, у издању нашег сјајног издавача одабраних дела из светске научно-популарне литературе, коначно је угледала светло дана и на домаћем тржишту. У оригиналу на енглеском језику књига је објављена 2018. године, да би већ 2019. године њен превод на српски језик доспео у руке домаћег читаоца.

Најпре о аутору и његовом опусу. Књига Кожа у игри представља наставак дубоког промишљања стварности једног од водећих стручњака за ризик, случајност, насумичност, неред и промишљања свега онога што је „ван стандардне девијације”. Технички речено, онога што је „на репу” и што се, према мишљењу аутора, не може никако предвидети, упркос мишљењу бројних „стручњака за контролу ризика” који нас уверавају да је то могуће. Дакле, најновија књига Н. Н. Талеба део је његовог опуса, у виду есеја, под називом „Инцерто” (Incerto), који чине (редом по годинама издања издавачке куће „Хеликс”): „Варљива случајност - скривена улога шансе у животу и на тржиштима” (прво издање из 2001. године); „Црни лабуд - утицај крајње невероватних збивања” (прво издање из 2007. године); „Прокрустова постеља" - филозофски и практични афоризми (прво издање из 2010. године) и „Антикрхкост - ствари којима прија неред” (прво издање из 2012. године). Иако ове књиге чине засебне целине и могу се читати насумично (да употребимо омиљени Талебов термин), у основи оне представљају повезани „мисаони експеримент”, те се многе идеје из новијих књига ослањају на раније изложене идеје и концепте. Тако и Кожа у игри представља природни наставак интелектуалног промишљања њеног аутора у вези са темом која чини срж његових књига: насумичност и случајност!

Овој теми, овога пута, аутор приступа из другог угла и како одмах (а Талеб је познат као неко ко не воли да околиша) у Уводу наглашава, она обједињује четири теме: 1) неизвесност и поузданост знања; 2) симетрију у људским

\footnotetext{
${ }^{a}$ Насим Николас Талеб, Кожа у игри - асиметрије скривене у свакодневници,
} Смедерево: Хеликс, 2019, стр. 275. 
односима, тј. коректност, одговорност, правичност и реципроцитет; 3) размену информација у трансакцијама; 4) рационалност у сложеним системима и стварном свету. У наставку аутор каже: „...колико су ове четири теме нераскидиво повезане, постаје очигледно када је нечија... кожса у игри".

Кључни концепт ове књиге, а уједно и наслов исте, јесте „кожа у игри”, који имплицира да не треба да обраћамо пажњу на то шта људи говоpe, већ само на оно шта чине (лат. facta non verba) и колико тога стављају на коцку. Речју, „кожа у игри” изражава нашу спремност да преузмемо ризик и све последице које он са собом носи. Управо овај концепт Талеб разрађује и наглашава да помоћу њега можемо разумети (наравно, никада у потпуности) свет који нас окружује, односно: 1) разликовати стварно од лажног (често наводи као пример разлику између правих и лажних стручњака, односно правих научника и оних који се баве сцијентизмом); 2) поступати тако да не нарушавамо симетрију и реципроцитет у нашим односима, односно да интернализујемо не само добитке него и терет (ризик) њиховог остварења, без пребацивања тог терета на друге; 3) разумети агенцијски проблем (principalagent problem) и схватити колико заиста информација треба да делимо са другима у односима који су асиметрични (рецимо, однос купац-продавац или адвокат-клијент); 4) схватити заиста шта је то рационалност и тест времена (тзв. „Линди ефекат”), коју (рационалност) Талеб врло убедљиво повезује са концептом преживљавања (опстанком).

Књига је врло интересантне структуре. Аутор је ове идеје изложио и разрадио у осам поглавља, односно, како их са̂м назива, „књига”. Након Увода, односно „Књиге 1”, где аутор износи етичке концепте, почев од Хамурабија преко Канта, до модерних времена, и полако на примерима упознаје читаоце са, такође, етичким концептом „коже у игри”, у „Књизи 2”, под називом „Први поглед на агенцију”, Талеб разматра агенцијски проблем (који је, у основи, економски концепт), да би му се поново подробније вратио у „Књизи 6”.

У међувремену, у „Књизи 3”, под називом „Та највећа асиметрија”, аутор износи бројне примере тзв. правила мањине, односно како најнетолерантнији побеђују. Рецимо, Талеб објашњава како један језик, следећи правило мањине, односи превагу над другим језицима, док ово правило не важи када су у питању гени. Такође, разматрајући етичке импликације овог правила, аутор указује на то да је потребно нетолерантно одговорити на бројне савремене нетолерантне мањине, попут разних екстремних терористичких организација.

У „Књизи 4”, под карактеристичним називом „Вукови међу псима”, Талеб објашњава како функционише савремени облик робовласништва (у коме доминирају велике корпорације), где се људи суптилним мерама (рецимо, уговором о раду) држе у покорности, попут паса. У вези с тим опширније пише на тему слободе и покреће питање цене слободе!

Чини се да је „Књига 5” најузбудљивија јер усмерава нашу пажњу на актуелну дебату која се води у Америци, где, иначе, Талеб живи и ради. Читалац се може упознати са полемиком која се води између Талеба, с једне стране, и истакнутих представника бихевиористичких наука (пре свега, бихевиористичке економије), која је праћена мноштвом оштрих (може се рећи и непотребних) речи и узајамних нападања. То се, пре свега, односи на сукоб Талеба и Талера (добитника Нобелове награде за економију и једног од 
водећих заступника либертаријанског патернализма), из кога се јасно може сагледати сукоб концепција. Талеб је неумољиви либертаријанац и неко ко користи концепте природних наука (подсетимо се да је он математичар и пробабилиста), док је Талер, као економиста, неко ко верује да држава може и треба да усмерава наше изборе, кроз тзв. архитектуру избора (остављање слободе појединцима да сами одлучују у контексту који ствара држава). Остављајући овај сукоб по страни, овај део књиге неспорно је врло информативан, јер нам оцртава савремену интелектуалну дебату која се води у Америци, као и степен развоја савремене интелектуалне свести.

„Књига 7” и „Књига 8” јесу најзанимљивије. Прво, аутор повезује „кожу у игри” са религијом и веровањем. Талеб објашњава сврху и функцију религија у свету, које се своде на опстанак људи, помоћу једноставних (често бинарних) правила која људи треба да следе. И управо ту, према мом мишљењу, аутор износи најузбудљивију тезу да рационалност чине сви они поступци коју су у функцији преживљавања! Рационалност се мери према поступцима, а не према веровањима! Следећи ову тезу, и сујеверни поступак може бити рационалан ако омогућава преживљавање. Штавише, Талеб прави разлику између оних који имају кожу у игри (који сносе сопствени ризик) и оних који имају кожу у игри за друге или дущу у игри, у које убраја, рецимо, Сократа или Христа!

Коначно, упутимо и неколико критичких напомена, пре свега, на стил и начин писања овог аутора. Наиме, Талеб је неко ко руши, и очито има снажну жељу да то чини, табуе и уврежена схватања, па и лицемерје у академским и другим круговима. Некада и он делује као „вук међу псима”, за шта је потребна велика доза интелектуалне храбрости. Иако је то легитиман начин писања који открива ауторов лични идентитет, ипак су у томе присутна одређена претеривања и непотребне генерализације када се, рецимо, економисти, психолози, банкари и други „стављају у исти кош”. Штавише, Талебова употреба (пре)оштрих речи, нарочито према неистомишљеницима, понекад оставља горак укус. Могуће је да на тај начин аутор привлачи више пажње и уједно аутентично исказује сопствено мишљење, али то не умањује утисак да неки закључци нису довољно уравнотежени.

Све у свему, Н. Н. Талеб зна о чему говори јер он, као дугогодишњи трговац и човек са искуством у трговини на финансијском тржишту, али и неко ко се предано и са огромном страшћу бави интелектуалним радом има кредибилитет да износи ставове у које верује. Једноставно, Талеб има „кожу у игри” и као такав он дели људе и њихова мишљења и уверења.

Као што са̂м аутор у овој књизи наводи, време, као најбољи судија, показаће да ли су његове идеје тачне и да ли имају кредибилитет. До тада, остаје да се књиге овог ерудите читају (можда и по неколико пута), јер оне имају невероватну моћ да заинтригирају савременог читаоца опхрваног празном и неутемељеном литературом и задрже његову пажњу. Дубина и луцидност јесу особине које красе овог аутора, а дошле су до изражаја и у најновијој књизи Кожа у игри. 